against trans people by not legally recognizing their gender identities, or only doing so under abusive and restrictive requirements.

Consequently, the Independent Expert concludes with a wealth of recommendations that seek to support States in upholding their human rights obligation vis-à-vis persons of diverse gender identities. States are urged to address violence and discrimination based on gender identity through laws, policies and judicial decisions, including the enactment of hate crime legislation that establishes transphobia as an aggravating factor. They are also urged to swiftly adopt the changes made by the WHO in the ICD in regard to trans categories to eradicate the conception of gender diversity as a pathology from all aspects of everyday life, to eliminate abusive requirements as prerequisites for change of name, legal sex or gender, including forced, coerced or otherwise involuntary sterilization, and to adopt legal gender recognition administrative procedures that are simple and based on self-determination.

Madrigal-Borloz has presented a comprehensive analysis of root causes of the violence and discrimination that trans people face globally in the context of pathologization and state recognition and protection, or rather the lack thereof. Such an investigation is unprecedented in the context of UN special procedures, and demonstrates the Independent Expert's commitment to elevate issues pertaining to gender identity. The report's timely and useful analysis has long been overdue in the context of the international human rights framework.

\section{Fallgirls: Gender and the Framing of Torture at Abu Ghraib (Classical and Contemporary Social Theory), by Ryan Ashley Caldwell.}

Published by Routledge Books. 2017. New York. (ISBN 978-1-4094-2969-2)

\section{Pau Pérez-Sales ${ }^{\star}$}

Initially published in 2012 and now reedited, this book constitutes a peculiar contribution to the torture literature on perpetrators. Existing books have already covered: self-justifying perspectives written by perpetrators (i.e. Aussaresses, 2010; Moore-King, 1998; Pardo, 2014; Troccoli, 1996); interviews with perpetrators or analysis from autobiographical texts (i.e. Conroy, 2000; Crelinsten \& Schmid, Alex P (Eds.), 1995; Haritos-Fatouros, 2003; Payne, 2008; Pérez-Sales, 2017); and analysis of the interaction from a survivor's viewpoint (Gil, 1999). There also exists a wealth of social psychology books that attempt to theorize the logic and dynamics of becoming a perpetrator (i.e. Bandura, Barbaranelli, Caprara, \& Pastorelli, 1996; Browning, 1992; Miller, 2004; Staub, 1999). Caldwell's book adopts the extreme hypothesis that the soldiers England and Harman, judged for acts of misconduct in Abu Ghraib after the leakage of dozens of terrible pictures,

*) Editor-in-Chief, Torture Journal

Correspondence to: pauperez@arrakis.es 
are innocent. The book goes on to defend the nearly untenable thesis that England and Harman must be considered victims themselves. It is thus wholly unsurprising to find out that Caldwell was part of the legal defence team for both soldiers.

In essence, the author depicts the soldier Sabrina Harman as an empathetic, supportive and well-intentioned person to whom the children of the villages around the prison looked to for gifts of food and candies (pp. 148-150). Harman is also depicted as maintaining relationships of friendship and camaraderie with the prisoners, in light of the atmosphere of laughter and jokes in the torture cells. Throughout this portrayal of Harman as a nice person caught in a terrible situation runs an unacknowledged disjuncture with the image of prisoner Gillian (Saad) on a cardboard box, seminaked, hooded, and with electric wires in his hands. The narrative attempts to reconcile these accounts by suggesting that Gillian's image on the box was part of a fun game in which Gillian himself (who would die shortly thereafter) happily participated ( $\mathrm{p}$. 77 ), even though the game's ultimate goal was to keep Gillian awake all night to be interrogated the next day.

Soldier Lynndie England is presented to the reader as a person of low intelligence that can be easily manipulated, with a dependent personality who obeys the orders of her sexual partner, soldier Charles Graner, who would be the real perpetrator (pp. 102-105 and 127 among others). For this to be possible, the author of the book points to a curious Baudrillardian inspired postmodern thesis: reality is what one constructs (Chapter 4). Given that the military court which judges these events describes them as "mistreatment" of detainees, carefully avoiding the word torture, and that the perpetrators are framed as victims, no other arguable thesis emerges to understand what happened in these cases. In this way, torture is made nonexistent by categorizing what perpetrators do as "a different thing" or justified by necessary security procedures.

In Fallgirls, postmodernism is a handmaiden to tolerating a situation in which naked, sleep-deprived people in permanent isolation (despite presenting psychotic symptoms) are handled like animals and humiliated as part of regular security measures. Under these twisted conditions, writing messages on the bodies of the detainees was accepted as a necessary safety procedure to protect soldiers from eventual "rapists" (pp. 160-164).

Defence lawyers could have opted for a different, more realistic, line of argument, though perhaps less promising in terms of achieving acquittal. In any process of perpetration of harm, there are four levels:

1. the ideologue who recreates the need and justification for a torturing system;

2. the planner who turns it into programs and rules;

3. the primary executor who plans and gives orders (or allows the necessary chaos) locally; and,

4. the immediate executor who finally perpetrates torture under the gaze of bystanders.

It is absolutely right that all soldiers (Harman and England too) are necessarily collaborators in a system they have not designed. A State torturer is always part of a broader torturing system. The system itself is designed with watertight compartments, to prevent those in charge in the upper levels from being impeached due to the actions of the executers. The legal system is therefore constructed to exonerate the political and military commanders and sentence the immediate executor (the 'rotten apple'). 
The immediate executor thereby becomes a scapegoat, which validates the system and projects an appearance of honesty. The defendants of both soldiers could have alluded to the cliché of the banality of evil (Arendt, 1973) and appealed to the logic that they were not a couple of "rotten apples" but part of a chain of command in a system that masks ultimate command responsibility. But this was not to be the case.

Fallgirls maintains that both of the soldiers are victims of the context.

Caldwell points to the most radical form of justification of perverse acts by context even though the literature on the social psychology of good and evil shows that context alone can never explain the perpetration of harm (Haslam \& Reicher, 2007). In particular, neither of the wellknown Milgram or Standford studies can provide an explanation of what happened because in each of them there is a margin of and for resistance. Forty percent of the subjects of Milgram's experiments resisted the pressure of the false researcher (Packer, 2008) and in the most important replication of the Stanford study, the existence of some figures' resistance to authority dismantles the paradigm of abuse and perpetration of harm in a prison (Reicher \& Haslam, 2006).

As an alternative hypothesis, Caldwell resorts to what she calls 'critical feminism.' She argues that the two female soldiers would have been immersed in a masculinist military collective institution with a homophobic structure organized around a binary stereotype of rational and powerful men versus emotional and irrational women (Chapter 2 and 3). In the attempt not to distance themselves from this collective environment, fuelled by their dependence on men and in pursuit of the maintenance of the harmony of the group, they ended up becoming witnesses, indeed mere witnesses, of what the male soldiers did, appearing in pictures because they were told to do so (p. 157ss).

In this case, it can therefore be interpreted that gendered pressure to comply is of such an unbearable strength that one cannot conceive of free will in these soldiers. What no previous model of conformity has dared to propose, Caldwell attempts to attribute to gender submission. This is questionable. Furthermore, can such a model be considered feminist? In other words, is it feminist to consider women powerless victims of a masculine environment and unfailingly subjected to it to the point of becoming torturers on account of gender? As Rijke (2013) points out, creating an image of women as passive victims means that women are treated in an abusive manner, through stereotyping women in a way that obfuscates their wideranging means of expressing agency and resistance and slots them into a system of reference based on victimhood (Apps \& Gow, 2018). A true critical feminist perspective, especially as applied to legal defence strategy, would reflect on the power that one possesses, and not simply the power one is denied (Zarrugh, 2012). As Gronnvoll (2013) points out, gender equality means that women ought be able to achieve opportunities previously reserved for men, not that they should be able to evade responsibility for their actions.

Soldier Sabrina Harman was sentenced to six months in prison which was later reduced to three. Soldier Lynndie England was sentenced to three years, a sentence that does not correspond with international law. By considering them guilty and giving them minimum sentences, the martial court protected the chain of command and those ultimately responsible. That said, the debate here does not revolve around whether they 
are innocent or guilty. To use Browning's (1992) expression, the two soldiers were probably "ordinary women" of a torture battalion. To attempt to apply feminism to explain and justify these facts is an abuse of theory that does feminism a disservice as a necessary and liberating theory of the human being. This book makes for uncomfortable reading.

\section{References}

Apps, L., \& Gow, A. (2018). Tortured confessions. In Male witches in early modern Europe. Manchester University Press. https://doi. org/10.7765/9781526137500.00008

Arendt, H. (1973). Eichmann in ferusalem: A Report on the banality of evil. New York: Penguin Books.

Aussaresses, P. (2010). The Battle of the Casbah: Terrorism and Counter-Terrorism in Algeria, 19551957.

Bandura, A., Barbaranelli, C., Caprara, G. V., \& Pastorelli, C. (1996). Mechanisms of moral disengagement in the exercise of moral agency. Fournal of Personality and Social Psychology, 71(2), 364-374. https://doi.org/10.1037/00223514.71.2.364

Browning, C. R. (1992). Ordinary Men: Reserve Police Battalion 101 and the Final Solution in Poland. New York: HarperCollins.

Conroy, J. (2000). Unspeakable acts, ordinary people. The dynamics of torture. An examination of the practice in three democracies. University of California Press.

Crelinsten \& Schmid, Alex P (Eds.), R. D. (1995). The politics of pain : torturers and their masters. Series on state violence, state terrorism, and human rights. Boulder, Colo. : Westview Press.

Gil, D. (1999). El Capitán Por Su Boca Muere, o, la Piedad de Eros: Ensayo Sobre la Mentalidad de un Torturador [The Captain For His Mouth Dies, or, the Pity of Eros: Essay on the Mentality of a Torturer]. Montevideo: Trilce.

Gronnvoll, M. (2013). Fallgirls: Gender and the Framing of Torture at Abu Ghraib. The British Fournal of Sociology, 64(2), 365-366. https://doi. org/10.1111/1468-4446.12022

Haritos-Fatouros, M. (2003). The psychological origins of institutionalized torture. London: Routledge.

Haslam, S. A., \& Reicher, S. (2007). Beyond the banality of evil: three dynamics of an interactionist social psychology of tyranny. Personality and Social Psychology
Bulletin, 33(5), 615-622. https://doi. org/10.1177/0146167206298570

Miller, A. G. (2004). The social psychology of good and evil. New York: The Guilford Press.

Moore-King, B. (1998). White Man, Black War. Zimbabwe: Baobab Books.

Packer, D. J. (2008). Identifying Systematic Disobedience in Milgram's Obedience Experiments: A Meta-Analytic Review. Perspectives on Psychological Science, 3(4), 301-304. https://doi.org/10.1111/j.17456924.2008.00080.x

Pardo, P. (2014). El Monstruo. Memorias de un interrogador (The Monster. Memories of an interrogator). Madrid, España: Libros del KO.

Payne, L. A. (2008). Unsettling accounts: neither truth nor reconciliation in confessions of state violence. Duke University Press.

Pérez-Sales, P. (2017). Psychological Torture: Definition, evaluation and measurement. London-New York: Routledge Books.

Reicher, S., \& Haslam, A. (2006). Rethinking the psychology of tyranny: The BBC prison study. British fournal of Social Psychology, 45(1), 1-40. https://doi.org/10.1348/014466605x48998

Rijke, A. (2013). Book review. Fallgirls: Gender and the Framing of Torture at Abu Ghraib. Women's Studies International Forum, 38, 150-151. https:// doi.org/10.1016/j.wsif.2013.02.008

Staub, E. (1999). The roots of evil: social conditions, culture, personality, and basic human needs. Pers Soc Psychol Rev, 3(3), 179-192. https://doi. org/10.1207/s15327957pspr0303_2

Troccoli, J. N. (1996). La ira de Leviatán. Del método de la furia a la búsqueda de la paz. [ The wrath of Leviathan. From the method of fury to the search for peace]. (Centro de Informaciones e Investigaciones del Uruguay, Ed.). Montevideo.

Zarrugh, A. (2012). Review of Fallgirls: Gender and the framing of torture at Abu Ghraib. Societies without Borders, 7(2), 260-263. https://doi. org/10.1177/1741659012466337 